\title{
Intraspecific biogeographic pattern breakage in the snapping shrimp Betaeus emarginatus caused by coastal copper mine tailings
}

\author{
Marco A. Lardies ${ }^{1, *}$, Matías H. Medina ${ }^{2}$, Juan A. Correa ${ }^{3}$ \\ ${ }^{1}$ Departamento de Ciencias Básicas \& Centro de Investigación en Ciencias Ambientales (CIENCIA-UST) \\ Universidad Santo Tomas, Ejercito 146, Santiago, Chile \\ ${ }^{2}$ CIEN Austral-Centro de Investigación en Nutrición, Tecnología de Alimentos y Sustentabilidad, \\ Universidad Austral de Chile, Campus Puerto Montt, Región de Los Lagos, Chile \\ ${ }^{3}$ Facultad de Ciencias Biológicas, Departamento de Ecología and Center for Advanced Studies in Ecology \& Biodiversity, \\ Pontificia Universidad Católica de Chile, Santiago, Chile
}

\begin{abstract}
Environmental gradients are common in nature, and geographically widespread species must cope with environmental differences between habitats. Environmental differences produce biogeographic patterns that can involve morphological, physiological, and life-history traits. The Bergmann's rule has been described as one of these ecological and evolutionary patterns, predicting an increase in body size towards colder climates. Human-induced polluting events could impair the performance and/or fitness of exposed individuals and populations. Thus, we hypothesized that species undergoing exposure to pollutants will show a breakage of the natural biogeographical variation of their fitness-related life-history traits. In northern Chile, copper mine tailings have been dumped continuously for more than $60 \mathrm{yr}$. Because the snapping shrimp Betaeus emarginatus is commonly found in intertidal pools near this dumping site, it was used as a study model. This shrimp has a pelagic larva and a wide distribution along the Chilean coast. Different life-history traits were studied in 5 populations over a range of 19 degrees of latitude along the Chilean coast. Population mean values for female body mass, egg volume, and reproductive output were positively correlated with latitude. In contrast, egg number was negatively correlated with latitude and positively correlated with temperature. Shrimps from the dumping site showed life-history trait values significantly lower than the range observed in areas with no copper enrichment, breaking the biogeographical patterns predicted by the Bergmann's rule. Such studies emphasize the need for integrating different concepts of organism and population ecology and life-history theory in the assessment of anthropogenic pollution.
\end{abstract}

KEY WORDS: Copper $\cdot$ Life-history traits $\cdot$ Biogeography $\cdot$ Intertidal rocky shore $\cdot$ Reproductive output · Chile

Resale or republication not permitted without written consent of the publisher

\section{INTRODUCTION}

Environmental gradients are common in nature, and, as a result, geographically widespread species have to cope with environmental differences between habitats. At a geographical scale, ectotherms distributed along environmental gradients (i.e. altitude, latitude) show systematic patterns of variation in several traits, supporting various biogeographical rules. The most obvious are related to body size, which is considered the most important quantitative trait of individuals (Blanckenhorn \& Demont 2004). In this context, different ecological and evolutionary patterns have been described: (1) Bergmann's rule (Atkinson \& Sibly 1997), which predicts an increase in body size towards areas with colder climates (i.e. higher latitudes/ 
altitudes); and (2) the converse Bergmann's rule (Mousseau 1997), which states that in annual ectotherms the increase in body size is observed towards lower latitudes.

For marine invertebrates, 2 rules have been specifically described, both closely related to individual fitness: (1) Thorson's rule (Thorson 1950), which establishes a shortening of the larval phase towards the poles; and (2) Clarke's postulate (Clarke 1987), which predicts an increase in reproductive output towards lower latitudes. These rules have been observed in different environments and in diverse spatial scales. At both intraspecific and interspecific levels, the mechanisms underlying these patterns remain unknown, and are currently subject for debate in several areas of biology (Blanckenhorn \& Demont 2004).

Human-induced polluting events can exert different effects on exposed individuals and/or populations, generating changes in community structure and ecosystem functioning (Parker et al. 1999). According to Medina et al. (2007), depending on the level and duration of the polluting events, these community and ecosystem changes can theoretically result from: (1) elimination of sensitive species due to direct toxic effects, (2) replacement of these species by less sensitive ones due to release from competition, (3) shifts in food-web interactions as a result of decreased predation and/or grazing of toxicant-susceptible species, (4) acclimation (physiological adaptation), and (5) selection of genetically inherited tolerance (genetic adaptation). Measurements of fitness and fitness-related life-history traits (i.e. survival, development, fecundity) have shown that the last 2 processes may involve fitness costs associated with the altered physiological processes that facilitate resistant individuals to cope with the toxic stress (Calow \& Forbes 1998, Notten et al. 2006). The existence of these trade-offs in populations that remain at affected sites could be indicative of a reduction in the population's growth rate (Weis \& Weis 1989) and/or of a modification in the way species exploit their ecological niches and participate in the overall ecosystem functioning (Medina et al. 2007).

In this context, we hypothesized that geographically widespread species undergoing exposure to pollutants will show a breakage of the natural biogeographical variation of their fitness-related life-history traits. We further hypothesized that knowing the natural pattern of life-history traits shown by species with ample geographic distribution would make it possible to recognize when an ecosystem is affected.

In the present study, the occurrence of this type of disruption was assessed in the geographically widespread marine shrimp Betaeus emarginatus, also found in a copper-enriched area of the northern Chilean coast. We attempted to gain an understanding of the possible mechanisms underlying the break in lifehistory traits (i.e. fitness costs) and of the mechanisms operating in an affected ecosystem.

\section{MATERIALS AND METHODS}

Shrimp and study sites. The snapping shrimp Betaeus emarginatus (Decapoda: Caridea: Alpheidae) was used as the study model. This species inhabits rocky intertidal pools from northern Peru to southern Chile (Wehrtmann \& López 2003). Its reproduction is characterized by females carrying large eggs, although they are produced in smaller quantities and at higher rates than other shrimps (Lardies \& Wehrtmann 1997).

Individuals of Betaeus emarginatus were collected during the spring of 2005 from 5 different localities along the Chilean coast, considering a latitudinal range of 19 degrees: Iquique $\left(20^{\circ} 12^{\prime} \mathrm{S}\right)$, Caleta Palito $\left(26^{\circ} 16^{\prime} \mathrm{S}\right)$, Pan de Azucar $\left(26^{\circ} 08^{\prime} \mathrm{S}\right)$, Guanaqueros $\left(30^{\circ} 07^{\prime} \mathrm{S}\right)$, and Valdivia $\left(39^{\circ} 49^{\prime} \mathrm{S}\right)$. Iquique, Guanaqueros, and Valdivia have no history of any significant polluting event. Caleta Palito, on the other hand, is located at the center of the Chañaral coastal system, which in 1938 began to receive wastes from the El Salvador copper mine (Castilla 1983). Until 1975, >150 × $10^{6}$ metric tons of untreated tailings were continuously dumped, affecting directly $>20 \mathrm{~km}$ of coastline (Castilla 1983). From 1976 to 1989 the discharge point moved to Caleta Palito, which received ca. $130 \times 10^{6}$ metric tons of tailing in $13 \mathrm{yr}$. After a sedimentation dam was built inland in 1990, sediment-free wastewaters were channeled from the dam to Caleta Palito at a flow rate of 200 to $250 \mathrm{l} \mathrm{s}^{-1}$. Studies performed in the area have shown a variable but persistently high concentration of total dissolved copper in coastal seawater (8.7 to $30.7 \mu \mathrm{g} \mathrm{l}^{-1}$ ), beach progradation, severe reduction in species richness, and a complete modification of the intertidal community structure (Medina et al. 2005). Due to its lack of a history of heavy metal pollution and its proximity to Caleta Palito (ca. $7 \mathrm{~km}$ north), Pan de Azucar has been considered a reference site. Recent studies have indicated that, whereas in Caleta Palito the concentration of free copper ions $\left(\mathrm{Cu}^{+2}\right)$ is $4.86 \mathrm{nM}$, in Pan de Azucar it does not reach levels higher than $0.5 \mathrm{nM}$ (Andrade et al. 2006).

Latitudinal gradient. In Chile, sea surface temperature (SST) decreases gradually from north to south. According to the information published by the Servicio Hidrográfico y Oceanográfico de la Armada de Chile (1996, www.shoa.cl/cendoc-jsp/index.jsp), the mean annual SST at Iquique is $16.62^{\circ} \mathrm{C}$ (1958 to 2006), ranging between 14.82 and $19.54^{\circ} \mathrm{C}$. Off Caldera, near Caleta Palito and Pan de Azucar, the mean annual SST 
is $15.98^{\circ} \mathrm{C}$ (1951 to 2006$)$, ranging between 13.95 and $18.08^{\circ} \mathrm{C}$. Coquimbo, near Guanaqueros, presents a mean annual $\mathrm{SST}$ of $15.59^{\circ} \mathrm{C}$, ranging from 13.54 to $17.67^{\circ} \mathrm{C}$ in the period from 1960 to 2006 . Off Valdivia, the mean annual SST is $12.90^{\circ} \mathrm{C}$ (1962 to 2006), ranging between 10.58 and $14.93^{\circ} \mathrm{C}$.

Seawater salinity off Iquique remains stable throughout the year, with a mean of $35.0 \%$ (1985 to 1995) and a variation from 35.3 to $34.8 \%$. In southern Chile (i.e. Valdivia), however, salinity varies seasonally, with lower values during the austral winter (32.1\% in July) and maximum values during the austral summer (33.6\%o in February). At this site, the mean for the period from 1985 to 1995 was 32.8\%. Near Guanaqueros, surface salinity has marginal seasonal fluctuations, with values varying from $34.0 \%$ (July) to $34.7 \%$ (November) and an annual mean of $34.3 \%$ (1985 to 1995).

Analysis of Betaeus emarginatus females and eggs. Females of $B$. emarginatus covering the whole size range for the species were collected from intertidal pools using a hand net. The numbers of sampled snapping shrimps were 160 in Iquique, 116 in Caleta Palito, 78 in Pan de Azucar, 205 in Guanaqueros, and 360 in Valdivia, including 40,39, 21, 46, and 72 ovigerous individuals, respectively. Shrimps were placed in individual, labeled bottles containing a fixative solution of $10 \%$ formaldehyde (diluted with seawater).

Carapace length (CL) was measured for each shrimp using a stereomicroscope with a calibrated eyepiece. Dry body mass $\left(m_{\mathrm{b}}\right)$ was also determined using an analytical balance with a precision of $\pm 0.01 \mathrm{mg}$. For this procedure, individuals were rinsed twice with distilled water and dried for $72 \mathrm{~h}$ at $60^{\circ} \mathrm{C}$. Eggs had been previously removed from each female, and their number (EN) determined. Egg lengths and widths were measured in 20 eggs female ${ }^{-1}$ to calculate the egg volume (EV) using the formula for the volume of an ellipsoid (see Lardies \& Wehrtmann 1997). The clutch volume was estimated from multiplication of the mean EV by the total EN. The developmental stage of the eggs was also determined following the criteria proposed by Lardies \& Wehrtmann (1997) — Stage I: eggs recently produced, uniform yolk, no visible eye pigments; Stage II: eye pigments barely visible; and Stage III: eyes clearly visible and fully developed, abdomen free. Considering that crustaceans, and particularly $B$. emarginatus, frequently lose eggs during their development (Lardies \& Wehrtmann 1997), the individual egg number was estimated only in females with eggs in Stage I (recently produced). Dry egg mass was finally determined following the methodology for $m_{\mathrm{b}}$. With this information, the reproductive output (RO) or biomass invested on reproduction by each female was estimated according to Clarke et al. (1991):

$$
\mathrm{RO}=\frac{\text { total mass of egg batch }}{\text { mass of female }}
$$

Statistical analyses. For each locality, linear regressions were performed with CL and EN. To test for differences in EV, both at intra-population (between different developmental stages) and at interpopulation levels (between similar stages), 1-way analyses of variance (ANOVA) were applied. The same analysis was used to estimate differences in female $m_{\mathrm{b}}$ and RO between sites. An analysis of covariance (ANCOVA) was used to evaluate differences in EN between localities, with female body size as the covariate. When differences between means were significant at $\mathrm{p}<0.05$, an a posteriori Tukey's HSD (honestly significant difference) multiple comparison test with Bonferroni correction was applied to determine which sites were significantly different from the others. The ANOVA assumptions were checked using the Kolmogorov-Smirnov and Cochran tests for normality, and the Hartley and Bartlett tests for homogeneity of variances. Finally, linear regressions among population mean values of all life-history traits studied (excluding copper-exposed population) were done, and the $95 \%$ confidence interval values were estimated.

\section{RESULTS}

\section{Size of ovigerous females}

Both average CL and $m_{\mathrm{b}}$ of Betaeus emarginatus decreased significantly (CL: $F_{4,185}=19.66$, $\mathrm{p}<0.001$; $\left.m_{\mathrm{b}}: F_{4,185}=21.77, \mathrm{p}<0.001\right)$ from high to low latitudes (Fig. 1). The a posteriori Tukey (HSD) test showed that female size was significantly smaller in Caleta Palito, with mean values for $\mathrm{CL}$ and $m_{\mathrm{b}}$ of $9.9 \pm 0.9 \mathrm{~mm}$ and $106.3 \pm 25.4 \mathrm{mg}$, respectively (Fig. 1). When data from Caleta Palito were excluded from the analysis, a significant and positive linear regression of body size increase with latitude was found $(\mathrm{CL}=0.1 \times$ latitude + 7.96, $\mathrm{r}^{2}=0.80, \mathrm{p}<0.05 ; m_{\mathrm{b}}=8.84 \times$ latitude -82.84, $\left.\mathrm{r}^{2}=0.88, \mathrm{p}<0.05\right)$. The mean body size of ovigerous females from Caleta Palito fell out of the $95 \%$ confidence interval (Fig. 1).

\section{Egg size and number}

A significant linear relationship between body size and egg number for all populations was found (Table 1). After removing the effects of body mass, differences in egg production between populations were also detected, with EN being higher at lower latitudes $\left(F_{4,185}=38.22, \mathrm{p}<0.001\right)$. This pattern was supported 

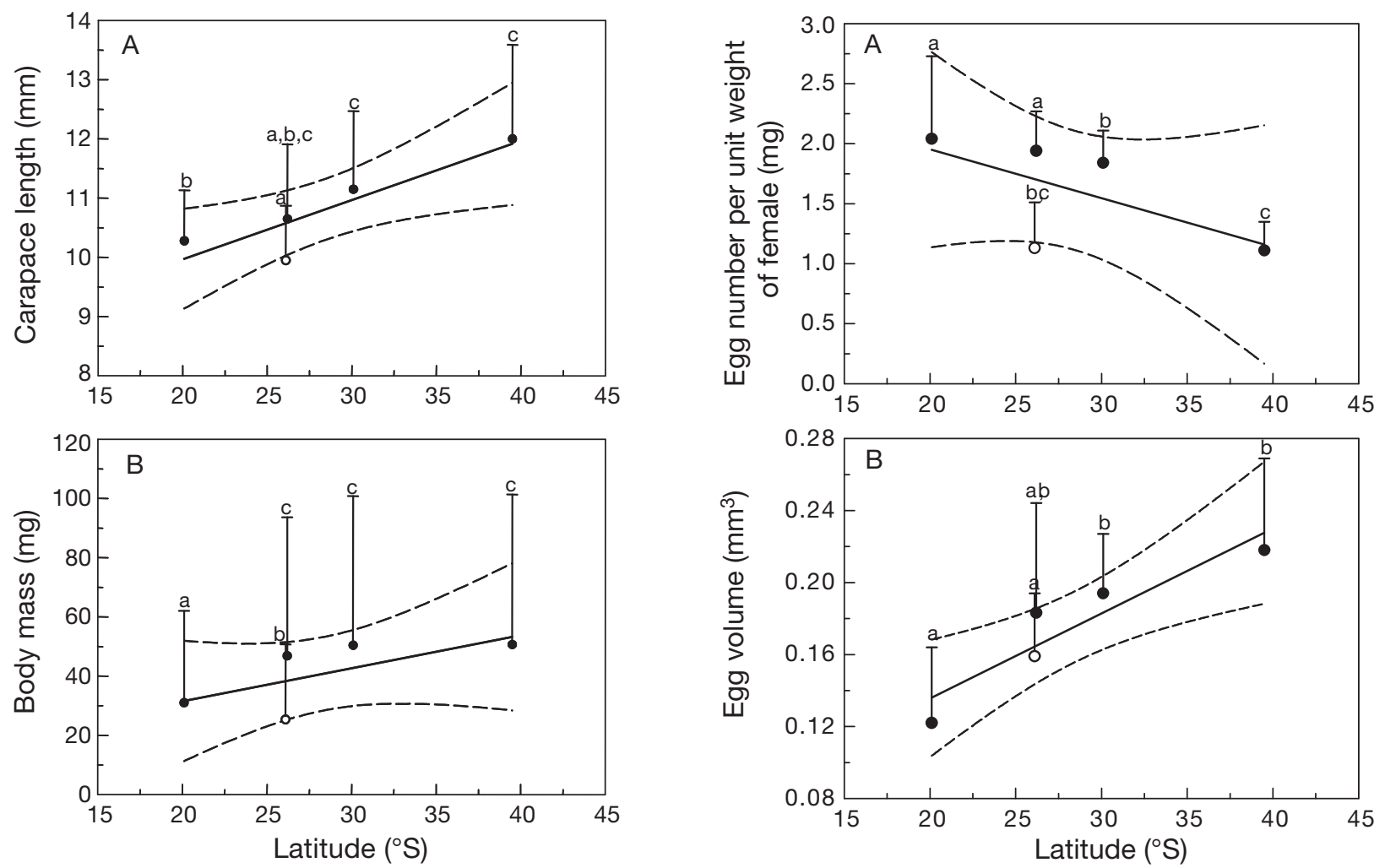

Fig. 1. Betaeus emarginatus. (A) Carapace length and (B) body mass of ovigerous females from different latitudes along the Chilean coast. Mean (+SE) values are indicated. Dashed lines: $95 \%$ confidence interval for means; open symbols: population at Caleta Palito. For statistics of the linear regressions see 'Results' section. Significant differences are shown by different letters

by the analysis of EN per unit of female body mass, where significant differences between sites $\left(F_{4,185}=\right.$ $78.62, \mathrm{p}<0.001)$ were detected. Those differences ranged from 2.04 eggs in Iquique to 1.11 eggs in Valdivia (see Fig. 2A), representing a gradual decrease toward higher latitudes $(\mathrm{EN}=-0.0407 \times$ latitude + $\left.2.7681 ; \mathrm{r}^{2}=0.51, \mathrm{p}<0.0001\right)$. At the intra-population

Table 1. Betaeus emarginatus. Linear regression equations for the estimation of egg production in each population. $r^{2}$ : coefficient of determination; EN: egg number per female; CL: female carapace length (in $\mathrm{mm}$ ); $\mathrm{n}$ : number of data points regarding females with freshly produced eggs (Stage I) included in each analysis; p: probability level of significance

\begin{tabular}{|lllll|}
\hline Locality & \multicolumn{1}{c}{ Regression } & \multicolumn{1}{c}{$\mathrm{r}^{2}$} & $\mathrm{p}$ & $\mathrm{n}$ \\
\hline Iquique & $\mathrm{CL}=12.26 \mathrm{EN}-93.38$ & 0.52 & $<0.001$ & 28 \\
Pan de Azucar & $\mathrm{CL}=52.53 \mathrm{EN}-261.06$ & 0.77 & $<0.001$ & 22 \\
Caleta Palito & $\mathrm{CL}=29.185 \mathrm{EN}-165.51$ & 0.31 & $<0.05$ & 25 \\
Guanaqueros & $\mathrm{CL}=55.99 \mathrm{EN}-318.07$ & 0.68 & $<0.001$ & 41 \\
Valdivia & $\mathrm{CL}=38.54 \mathrm{EN}-344.01$ & 0.70 & $<0.001$ & 38 \\
\hline
\end{tabular}

Fig. 2. Betaeus emarginatus. (A) Egg number per unit weight of female and (B) mean egg volume of freshly extruded eggs (Stage I) of $B$. emarginatus from different populations collected along the Chilean coast. Mean (+SE) values, based on mg dry weight, are indicated. Dashed lines: $95 \%$ confidence intervals for mean egg volume and mean fecundity, respectively; open symbols: population at Caleta Palito. For statistics of the linear regressions see 'Results' section. Significant differences are shown by different letters

level, EV was different between developmental stages within all populations (Iquique: $F_{2,38}=22.11, \mathrm{p}<$ 0.0001; Caleta Palito: $F_{2,36}=25.19, \mathrm{p}<0.0001$; Pan de Azucar: $F_{2,17}=30.16, \mathrm{p}<0.001$; Guanaqueros: $F_{2,40}=$ 41.04, $\mathrm{p}<0.001$; Valdivia: $\left.F_{2,67}=63.41, \mathrm{p}<0.001\right)$. The volume of recently hatched eggs was also significantly different among populations $\left(F_{4,165}=\right.$ 104.57, $\mathrm{p}<0.001$ ), increasing toward high latitudes in a significant and linear manner $(\mathrm{EV}=$ $0.0047 \times$ latitude $+0.0411 ; \mathrm{r}^{2}=0.95, \mathrm{p}<0.001$; see Fig. 2B). No significant differences in this trait were detected between shrimps from Caleta Palito and those from the remaining (i.e. nonpolluted) sites. EN (per mg of female), on the other hand, showed a significant decrease toward high latitudes (see above). Individuals from Caleta Palito, however, did not follow this pattern and showed significantly lower values of fecundity compared with the other studied populations (Tukey HSD test $; \mathrm{p}<0.05$ ). A negative phenotypic 


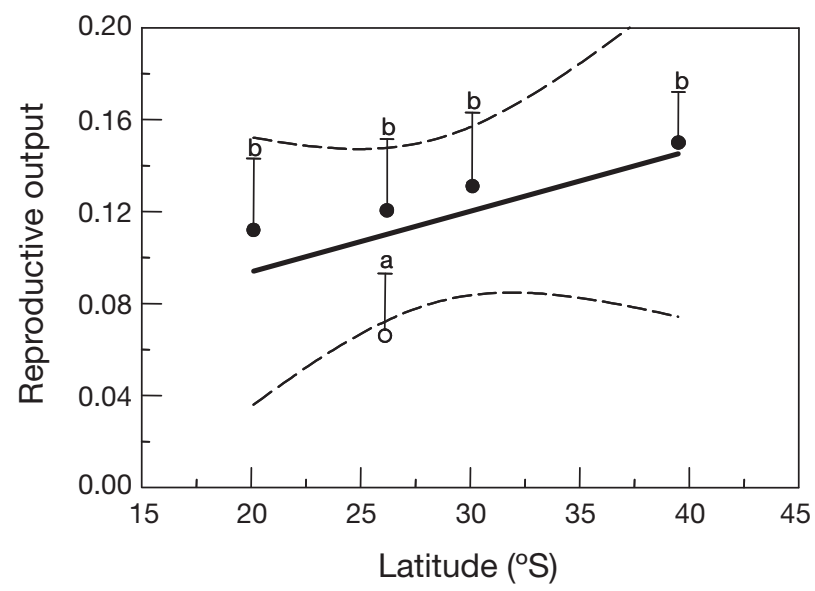

Fig. 3. Betaeus emarginatus. Reproductive output (RO) of females from different populations along a latitudinal cline. Mean (+SE) values, based on dry weight, are indicated. Dashed lines: $95 \%$ confidence interval for means; open symbol: population at Caleta Palito. For statistics of the linear regressions see 'Results' section. Different letters indicate significant differences (ANOVA and post hoc Tukey HSD tests)

correlation $\left(\mathrm{r}_{\mathrm{p}}=-0.44, \mathrm{p}<0.05\right)$ was observed between EV and EN per unit female body mass toward lower latitudes. Thus, individuals from southern populations (i.e. Valdivia) produced lower quantities of larger eggs, whereas in northern populations (i.e. Iquique) females produced larger quantities of smaller eggs.

\section{Reproductive output}

RO increased gradually toward higher latitudes $\left(\mathrm{RO}=0.0026 \times\right.$ latitude $+0.041, \mathrm{r}^{2}=0.57, \mathrm{p}<0.05 ;$ Fig. 3). The RO of shrimp from Iquique, Pan de Azucar, Guanaqueros, and Valdivia (Fig. 3) were 0.11 ( \pm 0.03 ), $0.12( \pm 0.03), 0.13( \pm 0.03)$, and $0.15( \pm 0.02)$, respectively. Thus, females invest about $11 \%$ of their body mass in egg production at lower latitudes (i.e. Iquique) compared with $15 \%$ at higher latitudes (i.e. Valdivia) (Fig. 3). The RO value of females from Caleta Palito $\left(0.066 \pm 0.03 ; 6.6 \%\right.$ of their $m_{b}$ in egg production) was significantly different from all other populations $\left(F_{4,165}=15.63, \mathrm{p}<0.001\right)$, falling outside the $95 \%$ confidence interval of the calculated regression (Fig. 3).

\section{DISCUSSION}

Our results show a wide latitudinal variation in body size of the snapping shrimp Betaeus emarginatus. CL and body mass values fit within the ranges reported for this species along the Chilean coast (Lardies \& Wehrtmann 1997). In spite of the above, females of $B$. emar- ginatus displayed a clear increase in body size toward higher latitudes, in agreement with previous observations of some ectotherms reportedly larger in colder environments (Atkinson \& Sibly 1997, Lardies \& Castilla 2001, Blanckenhorn \& Demont 2004). This pattern is of particular importance considering that body size is correlated with physiological, behavioral, and ecological traits (Fox \& Czesak 2000, Laptikhovsky 2006).

Latitudinal clines in body size with an established genetic basis have been reported in several ectotherms (Fischer \& Fiedler 2002). Diverse ecological variables are likely to be selective agents, with temperature being a key one (Fischer \& Fiedler 2002; but see Blanckenhorn \& Demont 2004). As indicated above, in Chilean coastal waters temperature decreases with latitude. In this context, our study showed that body mass of Betaeus emarginatus correlated significantly with latitude, in agreement with available information for other species of Chilean snapping shrimps (Lardies $\&$ Wehrtmann 2001). This information suggests a process of size selection on body mass with thermal environment and supports Bergmann's rule, which predicts an increase in body size toward higher latitudes or altitudes (Laptikhovsky 2006).

The smallest ovigerous females of Betaeus emarginatus amongst the studied localities were found in Caleta Palito. This small size is probably caused by the energetic costs of living in a habitat with high concentrations of copper. Based on the allocation principle, females in Caleta Palito are probably investing more energy in metabolism (i.e. maintenance, osmoregulation, and detoxification) and less in growth, as reported for other crustacean species (Garnacho et al. 2001). Although there is limited empirical evidence supporting the idea that detoxification imposes a direct energetic burden (Van Straalen \& Hoffmann 2000), 2 aspects support this assumption in the case of $B$. emarginatus from Caleta Palito. First, biologically active copper has remained chronically high in Caleta Palito and surroundings due to the mine tailing discharge (Andrade et al. 2006) and to the re-suspension of old coastal sediment. Second, although copper is an essential micronutrient for normal growth and development (Lesser 2006), and in decapods it is a fundamental component of hemocyanin, excessive amounts of this metal are lethal to crustaceans (Scelzo 1997). Different authors have reported a gradual loss of the osmoregulatory function and diminished gas exchange in decapod crustaceans when exposed to increasing concentrations of copper (Spicer \& Weber 1992). Harris \& Santos (2000) found alterations of numerous physiological parameters and a reduced growth rate in crabs inhabiting a copper-enriched mangrove habitat in Brazil. Furthermore, high concentrations of copper 
have resulted in reduced growth rates of larval and post-larval stages of various shrimp species, inhibition of reproduction, and negative effects on egg fertilization (Wong et al. 1995, Scelzo 1997). On the other hand, egg volume (size) did not change drastically in Caleta Palito, remaining within the natural latitudinal variation for the species, which suggests that larval size most likely does not deviate significantly from the species mean (see Wehrtmann \& López 2003). In spite of the above, subsequent larval and post-larval growth must be affected by the presence of copper, as indicated by individuals of smaller size compared with those from non-polluted populations.

Betaeus emarginatus females from lower latitudes are smaller when they start producing eggs than females from higher latitudes, which is in agreement with previous observations in several species of crustaceans (Jones \& Simons 1983, Lardies \& Castilla 2001). When considering egg production in equally sized ovigerous females of $B$. emarginatus, the number of eggs per unit weight of female increased from high to low latitudes, except in Caleta Palito. This result coincides with previous reports for different species whose egg sizes are negatively correlated with egg number (Wilhelm \& Schindler 2000). In the present study, northern populations produced larger quantities of small eggs, while intermediate- and high-latitude populations produced smaller quantities of larger eggs. Assuming that the same amount of energy is invested in egg production at all latitudes, theory predicts that a female can produce a large quantity of small eggs or a smaller quantity of large eggs. This trade-off is known to occur in many invertebrates (Clarke et al. 1991). Our results show that the reproductive output increased with latitude; hence, although the trade-off between egg number and egg size persists, the same amount of energy is not invested by all females. As a consequence of water uptake during embryonic development, egg volume in B. emarginatus increases, remaining within the range of variation reported for other crustaceans from Chilean coastal habitats (Lardies \& Wehrtmann 1997, 2001). The higher increase in egg volume in the southern localities may be related to greater fluctuations in environmental variables (Bauer 1992). Low variability in different environmental factors (i.e. salinity and temperature) at low latitudes, in comparison with the intermediate- to high-latitude sites, may facilitate the production of smaller eggs, with a smaller increase in volume throughout the development of the embryo. Clarke (1993) reported a similar relationship for shrimps, concluding that differences in egg size reflect real differences in per embryo maternal investment.

Most available information suggests that reproductive output of polar species is lower than that of species inhabiting temperate zones (Clarke 1987). This contradicts our findings showing that reproductive output of Betaeus emarginatus increased toward higher latitudes, as well as others reporting similar patterns for other marine crustaceans (Lardies \& Castilla 2001). In this study, low-latitude females invest about $10 \%$ of their body mass in egg production compared with $13 \%$ of females at higher latitudes. The latter suggests that individuals exposed to higher temperatures allocate more energy to rapid growth and higher metabolic rates, and invest less energy in reproduction. In contrast, the slow growth and low metabolism of species inhabiting low-temperature habitats allow for greater energy investment in egg production, because eggs contain larger internal reserves (Lardies \& Castilla 2001, Lardies \& Wehrtmann 2001). In other words, at low latitude, individuals increase maintenance costs and thereby reduce investment in growth and/or reproduction. Alternatively, it could be that females at higher latitudes simply delay reproduction while storing more energy. Thus, they would modify development time, which is an important trait for adapting to season length, as opposed to temperature (i.e. latitude) per se (Bauer 1992, Blanckenhorn \& Demont 2004).

Because of the above (i.e. high maintenance costs), reproductive output of snapping shrimps appears diminished at Caleta Palito (5\% of their body mass in egg production). This reduction in reproductive output (i.e. reproductive effort) in the presence of copper is known for several other species of crustaceans inhabiting polluted habitats (see Wong et al. 1995, Harris \& Santos 2000, Garnacho et al. 2001). Thus, the alteration of metabolism with copper exposure may require deviation of energy away from reproduction, resulting in lower reproductive effort compared with that of other populations inhabiting non-polluted sites. Although information regarding the mechanisms by which copper excess affects the metabolism of marine invertebrates is scarce, there is evidence that a so-called oxidative stress condition develops in some marine species when exposed to excesses of this metal (Livingstone 2001). Organisms undergoing oxidative stress must invest energy to activate the various antioxidant mechanisms, including de novo synthesis of antioxidant compounds and enzymes and, in more severe cases, repair cell and tissue damage. It seems likely that at least part of the energy required to buffer the oxidative stress caused by copper is subtracted and redirected from other normal metabolic activities, like growth and reproduction.

Overall, females of snapping shrimps show a wide range of latitudinal variation in all life-history traits analyzed. Fecundity was lower in low-latitude populations, while egg volume, body mass, CL, and reproductive output was higher at higher latitudes. However, 
mean trait values in shrimp population from the copper-enriched coastal site were far off the latitudinal gradual variation recorded for the species. The latter demonstrated a breakage of the natural biogeographic variation of fitness-related life-history traits, associated with a human-induced polluting event. Although our data prevent drawing conclusions regarding the type of adaptations that allow Betaeus emarginatus to inhabit this copper-enriched coastal site (i.e. physiological or genetic adaptations), it is clear that the presence of this population at Caleta Palito is associated with an expensive physiological regulation that likely has fitness costs. This trade-off could have significant ecological consequences, as it could be indicative of a reduction in the population natural growth rate (Weis \& Weis 1989) and/or of a modification in the way the species exploits its ecological niche and participates in the overall ecosystem functioning (Medina et al. 2007).

Finally, our findings contribute to the general knowledge gathered around the ecological impacts generated by the copper mine tailing discharges in the Chañaral coastal system. According to Medina et al. (2007), changes in community structure and ecosystem functioning in the affected area could result from 5 different ecological effects (see 'Introduction'). Whereas the first 3 have been addressed in previous studies (Castilla 1983, Correa et al. 2000, Medina et al. 2005), the last 2 can now be suggested from this study.

Acknowledgements. We thank 3 anonymous reviewers for constructive comments on a previous version of this contribution. This research was funded partially by FONDECYT 3040042 (M.A.L.) and by FONDAP 1501-0001 (Program 7) and an ICA research grant to J.A.C. The FNDR program is acknowledged for partial funding of M.H.M., supported by the Regional Government of Los Lagos (BIP: 30038191-0), and regional project No. R04I1003, supported by CONICYT. We thank Nesko Kuzmicic for female shrimp specimens collected in Pan de Azucar. This study complies with current Chilean legislation regarding the collection and treatment of invertebrates.

\section{LITERATURE CITED}

Andrade S, Moffett J, Correa JA (2006) Distribution of dissolved species and suspended particulate copper in an intertidal ecosystem affected by copper mine tailings in northern Chile. Mar Chem 101:203-212

Atkinson D, Sibly RM (1997) Why are organisms usually bigger in colder environments? Making sense of a life history puzzle. Trends Ecol Evol 12:235-239

Bauer RT (1992) Testing generalizations about latitudinal variation in reproduction and recruitment patterns with sicyonid and caridean shrimp species. Invertebr Reprod Dev 22:193-202

Blanckenhorn WU, Demont M (2004) Bergmann and converse Bergmann latitudinal clines in arthropods: two ends of a continuum. Integr Comp Biol 44:413-424

Calow P, Forbes VE (1998) How do physiological responses to stress translate into ecological and evolutionary processes? Comp Biochem Physiol 120A:11-16

Castilla JC (1983) Environmental impacts in sandy beaches of copper mining tailing at Chañaral, Chile. Mar Pollut Bull 14:159-164

Clarke A (1987) Temperature, latitude and reproductive output. Mar Biol 38:89-99

Clarke A (1993) Egg size and egg composition in polar shrimps (Caridea: Decapoda). J Exp Mar Biol Ecol 168: 189-203

Clarke A, Hopkins CCE, Nilssen EM (1991) Egg size and reproductive output in the deepwater prawn Pandalus borealis Krøyer, 1838. Funct Ecol 5:724-730

Correa JA, Ramírez MA, de la Harpe JP, Román D, Rivera L (2000) Copper, copper mining effluents and grazing as potential determinants of algal abundance and diversity in northern Chile. Environ Monit Assess 61:267-282

Fischer K, Fiedler K (2002) Reaction norms from age and size at maturity in response to temperature: a test of the compound interest hypothesis. Evol Ecol 16:333-349

Fox CW, Czesak ME (2000) Evolutionary ecology of progeny size in arthropods. Annu Rev Entomol 45:341-369

Garnacho E, Tyler PA, Peck LS (2001) Reproduction, seasonality, and copper toxicity in the coastal mysid Praunus flexuosus. J Mar Biol Assoc UK 81:433-440

Harris RR, Santos MCF (2000) Heavy metal contamination and physiological variability in the Brazilian mangrove crabs Ucides cordatus and Callinectes danae (Crustacea: Decapoda). Mar Biol 137:691-703

Jones MB, Simons MJ (1983) Latitudinal variation in reproductive characteristics of a mud crab, Helice crassa (Grapsidae). Bull Mar Sci 33:656-670

Laptikhovsky V (2006) Latitudinal and bathymetric trends in egg size variation: a new look at Thorson's and Rass's rules. PSZN I: Mar Ecol 27:7-14

> Lardies MA, Castilla JC (2001) Latitudinal variation in the reproductive biology of commensal crab Pinnaxodes chilensis (Decapoda: Pinnotheridae) along the Chilean coast. Mar Biol 139:1125-1133

Lardies MA, Wehrtmann IS (1997) Egg production in Betaeus emarginatus (H. Milne Edwards, 1837) (Decapoda: Alpheidae): fecundity, reproductive output and chemical composition of eggs. Ophelia 49:165-174

Lardies MA, Wehrtmann IS (2001) Latitudinal variation in the reproductive biology of Betaeus truncatus (Decapoda: Alpheidae) along the Chilean coast. Ophelia 55:55-67

> Lesser MP (2006) Oxidative stress in marine environments: biochemistry and physiological ecology. Annu Rev Physiol 68:253-278

> Livingstone DR (2001) Contaminant stimulated reactive oxygen species production and oxidative damage in aquatic organisms. Mar Pollut Bull 42:656-666

Medina M, Andrade S, Faugeron S, Lagos N, Mella D, Correa JA (2005) Biodiversity of rocky intertidal communities associated with copper mine tailing discharges in northern Chile. Mar Pollut Bull 50:396-409

Medina MH, Correa JA, Barata C (2007) Micro-evolution due to pollution: possible consequences for ecosystem responses to toxic stress. Chemosphere 67:2105-2114

Mousseau TA (1997) Ectotherms follow the converse Bergmann's rule. Evolution 51:630-632

Notten MJM, Oosthoek AJP, Rozema J, Aerts R (2006) Heavy metal pollution affects consumption and reproduction of the landsnail Cepaea nemoralis fed on naturally polluted Urtica dioica leaves. Ecotoxicology 15:295-304

$>$ Parker ED, Forbes VE, Nielsen SL, Ritter C and others (1999) Stress in ecological systems. Oikos 86:179-184 
Scelzo MA (1997) Toxicidad del cobre en larvas nauplii del camarón commercial Artemesia longinaris Bate (Crustacea, Decapoda, Penaeidae). Invest Mar 25:177-185

Servicio Hidrográfico y Oceanográfico de la Armada de Chile (1996) Atlas Oceanográfico de Chile, Vol 1 (18²1'S a $\left.50^{\circ} 00^{\prime} \mathrm{S}\right)$. SHOA, Valparaíso

Spicer JI, Weber RE (1992) Respiratory impairment by waterborne copper and zinc in the edible crab Cancer pagurus (L.) (Crustacea: Decapoda) during hypoxic exposure. Mar Biol 112:429-435

Thorson G (1950) Reproductive and larval, ecology of marine bottom invertebrates. Biol Rev Camb Phil Soc 25:1-45

Van Straalen NM, Hoffmann AA (2000) Review of experimental evidence for physiological costs of tolerance to toxicants. In: Kammega JE, Laskowski R (eds) Demogra-

Editorial responsibility: Otto Kinne,

Oldendorf/Luhe, Germany phy in ecotoxicology. John Wiley \& Sons, Chichester, p 115-124

Wehrtmann IS, López G (2003) Effects of temperature on the embryonic development and hatchling size of Betaeus emarginatus (Decapoda: Caridea: Alpheidae). J Nat Hist $37: 2165-2178$

Weis JS, Weis P (1989) Tolerance and stress in a polluted environment. Bioscience 39:89-95

Wilhelm FM, Schindler DW (2000) Reproductive strategies of Gammarus lacustris (Crustacea: Amphipoda) along an elevation gradient. Funct Ecol 14:413-422

Wong CK, Cheung JKY, Chu KH (1995) Effects of copper on survival, development and growth of Metapenaeus ensis larvae and postlarvae (Decapoda: Penaeidae). Mar Pollut Bull 31:416-419

Submitted: April 4, 2007; Accepted: November 21, 2007

Proofs received from author(s): April 8, 2008 